\title{
İş Sağlığı ve Güvenliği Uygulamalarının Örgütsel Bağlılığa Olan Etkisi: Bir Alan Araştırması
}

DOI: $10.26466 /$ opus.627786

\section{Mehmet Güler *}

* Dr. Öğr. Üyesi İstanbul Üniversitesi, İktisat Fakültesi, Beyazıt / İstanbul / Türkiye E-Posta: mehmetguler86@gmail.com

ORCID: $\underline{0000-0002-2956-7604}$

\section{Öz}

Sanayi devrimi ile birlikte gelişen fabrika tipi üretim sürecinde, çalışan sağlığı açısından ortaya çıkan olumsuz sonuçların iyileştirilmeye başlamasıyla birlikte iş sağlı̆̆l ve güvenliği kavramı gündeme gelmeye başlamıştır. İş sağhl̆̆ı ve güvenliği, iki farklı kavram gibi gözükmesine rağmen bir bütünü oluşturmaktadır. Günümüzde özellikle sanayileşmenin artması ile birlikte her yıl milyonlarca iş kazası ve meslek hastahı̆g meydana gelmektedir. Bu sebeple iş sağhl̆̆g ve güvenliği politikalarmnn geliştirilmesi ve derinlemesine incelenmesinin önemi artmaktadır. Günümüzde postmodern çalışma sistemi işveren ve çalışan arasındaki ilişkiye zarar vermektedir. Gün geçtikçe çalışanların işletmelerine karşı çeşitli nedenlerle bağhllıkları zayıflamaktadır. Geçmişten günümüze sağllk ve güvenliğin insan hayatı açısından önemi düşünüldü̈̆̈̈̈nde; iş sağhlğı ve güvenliği unsurlarının çalışanların bağlılığını etkileyen bir unsur olarak görmek doğru olacaktır. İş sağllğg ve güvenliği uygulamalarının tam olarak uygulandığı iş yerlerinde çalışanlar, kendilerine değer verildiği duygusu ile örgüte olan bağlıkların arttırırlar. İş sağglı̆̆ ve güvenliğinden yoksun çalışanlar, emniyet ve güvenlik duygusundan da yoksun olacă̆ından dolayı bir hoşnutsuzluk içine girerler, işyerine ve işlerine karşı olumsuz tutumlar geliştirirler. Bu çalışmanın temel amacl, iş sağhı̆̆ı ve güvenliği uygulamalarının örgütsel bağhllı̆̆a olan yansımaların incelemektir. Araştırmada, çalışanların iş sağllğı ve güvenliği algı düzeyi ile örgütsel bağlllık düzeyi arasında varsa ilişkiler, yönleri ve düzeyleri tespit edilmeye çalışllmıştır. Araştırmada kullanılan veriler, belli bir zamanda anket formları ile çalışanlardan toplanmış ve değişkenler arasında iliş̧ki olup olmadı̆̆̆ araştıılmıştır.

Anahtar Kelimeler: Işs Sağhlğğ ve Güvenliği, Örgüt Kültürü, Örgütsel Bağlllık 


\title{
The Impact of Occupational Health and Safety Practices on Organizational Commitment: A Field Study
}

\begin{abstract}
In the factory-type production process that accompanied the industrial revolution, the concept of occupational health and safety emerged as the negative consequences of workers' health began to be improved. Occupational health and safety form a whole, although it does not look like two different concepts. Today, especially with the increase of industrialization, millions of business accidents and occupational diseases occur every year. For this reason, occupational health and safety have become important for economic and social reasons. Today, the relationship between the employer and the employee of the postmodern system is damaged. Day by day, employees' loyalty to their businesses for various reasons is weakening. Considering the importance of health and safety for human life from past to present; occupational health and safety is a factor that affects employee loyalty. Occupational health and safety practices, workplace workers increase their sense of humor and ties when they are valued. Employees lacking occupational health and safety, lack of safety and security feelings come into dissatisfaction and develop negative attitudes towards the workplace and business. The main purpose of this study is to examine the effects of occupational health and safety practices on organizational commitment. In the research, it has been tried to determine the relationships, levels and levels between the level of employees' health and safety and the level of organizational commitment. The data used in the research were searched for whether there is a relationship between employees and a certain time and formulas.
\end{abstract}

Keywords: Occupational Health and Safety, Organizational Culture, Organizational Commitment. 


\section{Giriş}

İş sağlığı ve güvenliği uygulamaları her geçen gün daha da önem kazanarak, gelişmiş ve gelişmekte olan ülkelerin kalkınma düzeylerinin bir belirleyicisi haline dönüşmüştür. Ceylan (2011)'e gore iş güvenliği kavramı, "işyeri ve iş ortamında sağlıklı ve güvenli çalışma koşullarını oluşturarak; iş kazaları ve meslek hastalıklarını en alt düzeye indirmek böylece maddi ve manevi kayıpları önleyerek verimliliği artırmak şeklinde ifade edilebilir." Büyük ölçüde maddi ve manevi kayıplara neden olan iş kazaları ve meslek hastalıklarını önlemeye çalışmak, hem işletmelerin, hem devletin hem de çalışanların ortak sorumluluğudur.

Çalışanlar için iş sağlığ1 ve güvenliği uygulamalarının gerçekleştirildiği işyerleri bir tatmin kaynağıdır. İş sağlı̆̆ı ve güvenliği uygulamalarının tam olarak uygulandığı iş yerlerinde çalışanlar, kendilerine değer verildiği duygusu ile örgüte olan bağlıklarını arttırırlar. Örgüte bağlılık gösteren çalışanların, ayn zamanda yüksek düzeyde üretken oldukları; sadakat, verimlilik ve sorumluluk duygusuyla hareket ettikleri görülmektedir. İs sağlı̆̆1 ve güvenliğinden yoksun çalışanlar, emniyet ve güvenlik duygusundan da yoksun olacağından dolayı bir hoşnutsuzluk içine girererek işyerine ve işlerine karşı olumsuz tutumlar geliştirirler. İşlerine karşı olumsuz tutum geliştirenlerin aynı zamanda örgüte olan bağllı̆̆g da ortadan kalkmaktadır. Örgütsel bağlılığı azalan çalışan için işe geç gelme, devamsızlık yapma, işe yabancılaşma ve işten ayrılma gibi sonuçları ortaya çıkmaktadır.

Bu çalışmanın temel amacı, iş sağlığ 1 ve güvenliği uygulamalarının örgütsel bağlılığa olan yansımalarını incelemektir. Araştırmada, çalışanların iş sağlığı ve güvenliği alg1 düzeyi ile örgütsel bağl1lık düzeyi arasında varsa ilişkiler, yönleri ve düzeyleri tespit edilmeye çalışılmıştır.

\section{Kavramsal Çerçeve}

\section{IsşSağlığı ve Güvenliğinin Önemi}

İnsanoğlu varoluşundan beri çalışma kavramının çeşitli türleri ile hayatına yön vermiştir. Çalışma, doğada başlamış, sanayi sistemine evrilmiş devamında da hizmetler sektörünün çeşitli türlerinde evrim geçirmiştir. Hayatına devam edebilmesi için çalışmak zorunda olan insanoğlu, çalışma siste- 
mine dahil olduğu her yerde sağlık ve güvenlik açısından risk ve tehlike altına girmektedir. İş sağllğı ve güvenliği tedbirleri, çalışma hayatında insanın sağlık ve güvenlik açısından sorumluluklarını yerine getirmesini sağlayan politikalar olarak tanımlanmaktadır.

İş sağlığı ve güvenliği kavramının ele alınma sürecine bakıldığında ise; öncelikli olarak iş sağlığ 1 ve iş güvenliği olarak iki boyutta incelendiği görülmektedir. Uluslararası Çalışma Örgütü (ILO) ve Dünya Sağlık Örgütü (WHO) iş sağllğı kavramını; "hangi işi yaparlarsa yapsınlar bütün çalışanların fiziksel, ruhsal ve sosyal refahlarının mümkün olan en yüksek düzeye çıkarılmasını ve burada tutulmasını; çalışma koşullarından kaynaklanan sağlık sorunlarının önlenmesini; işçilerin işleriyle ilgili olup sağlığa zararlı risklerden korunmalarını; işçilerin fiziksel ve biyolojik kapasitelerine uygun mesleki ortamlarda çalıştırılmalarını; özetle işin insana, insanın da işine uygun getirilmesi"'ni hedefleyen uygulamalar olarak tanımlamaktadir.(Aybora, 2012, s.12)

İş güvenliği kavramı ise; "işyeri ve iş ortamında sağlıklı ve güvenli çalışma koşullarını oluşturarak; iş kazaları ve meslek hastalıklarını en alt düzeye indirmek böylece maddi ve manevi kayıpları önleyerek verimliliği artırmak şeklinde ifade edilebilir. İş güvenliğinde amaç, kişi sağlığını tehdit eden, tehlikeye sokan, milli ekonomiye zarar veren, kaza ve meslek hastalığ dediğimiz olayları önlemek ve çalışanın sağlı̆̆ını korumak" olarak tanımlanmaktadır.(Ceylan, 2011, s.19)

İş sağlığı ve iş güvenliği anlayışını birleştirerek ortaya bütüncül bir yaklaşım koyan iş sağlığı ve güvenliği kavramının tanımı ise; "tehlikelerin önlenerek ortaya çıkabilecek risklerin değerlendirilmesi, tedbirlerin alınması ve ortadan kaldırabilmek ya da zararlarını en aza indirebilmek adına çalışmalar yürütülmesi" olarak tanımlanmaktadır. Özkılıç tarafından yapılan bir başka tanımlama da ise iş sağlığı ve güvenliği, "henüz bir tehlike oluşmamış, işletmede bir arıza oluşmamışken bile işletmede oluşabilecek tehlikelerin ve risklerin öngörülerek bunların kabul edilebilir olup olmadığına karar verme çalışmaların da beraberinde getirmektedir ve konuyu "proaktif" yaklaşım" olarak ifade edilmektedir.

Geçmişten günümüze insanoğlunun çalışma hayatında rolü ve öneminin arttı̆̆ görülmektedir. Gelinen nokta da çalışma hayatında hizmet yoğun çalışma türlerinin arttığı görülmektedir. Buradan hareketle de, çalışma unsurunun içerisinde insanın rolü ve önemi arttıkça performansının önemi 
artmakta ve çalışanların sağlık ve güvenliğinin performansını etkileyen temel unsurlar olduğu düşünüldügüünde de iş sağllğı ve güvenliğine verilmesi gereken önem hergeçen gün artmaktadır.

İş sağlığı ve güvenliği anlayışına bakışı bir adım öteye taşıdığımız zaman ise toplum refahını etkileyen öneme sahip olduğu ifade edilmektedir. Yeterli önlemlerin alınmaması, iş sağlı̆̆ı ve güvenliği bilincinin oturmaması ve eğitimin verilmemesi durumunda yaşanacak iş kazaları ve meslek hastalıklarındaki artış doğrudan ve dolaylı maliyetleri ile önce çalışanlara sonra işverenlere ve devlete ağır sonuçlar ortaya çıkarmaktadır. Gelişmiş ülkeler iş sağlığı ve güvenliğine yaklaşımı bu açıdan ele almakta ve denetim uygulamaları, hukuki uygulamaları ve İSG kültürü oluşturulması gibi konuyu kapsamlı ele almaktadırlar.

Günümüzde artan sanayileşme, diğer taraftan hizmetler sektörünün ortaya çıkardığı çalışma alanlarındaki farklı risk ve tehlike faktörleri iş sağlığı ve güvenliğinin sürekli güncel olarak incelenmesi gereken bir konu olmasinı zorunlu kılmaktadır. Ancak, özellikle gelişmekte olan ülkeler ve gelişmemiş ülkelere bakıldığında İSG uygulamaları sadece kanunlar çerçevesinde ele alınan ve bir hukuk metninden öte gitmeyen konumdadır. Uygulamada yapılmayan denetimler ve çalışanların bilinçsizliği birçok maddi yükü işçi,işveren ve devlete yüklemektedir. İş sağllğ 1 ve güvenliği, tüm paydaşlar açısından ciddiyetle ele alınması gereken çalışma unsurunun en önemli konuları arasında yer alması gerekmektedir. İşçi, işveren ve devlet açısından görünür ve görünmez maliyetler arttıkça toplumsal refahı etkileyecek ağır sonuçlar ortaya çıarmaktadır.

İşçiler açısından konu ele alındığında, meydana gelen bir iş kazası bireyi işgücünden kayıp yaşaması, uzuv kayıbı yaşaması ve ölüm gibi birçok şekilde mağdur etmektedir. Geçimini, emeği karşılığında elde ettiği ücret ile sağlayan çalışanlar, meydana gelebilecek iş kazası veya meslek hastalıkları sonucundan elde ettikleri ücretlerden muaf olabilecek sonuçlar ile karşı karşı kalacaktır. İlk olarak, işgücünden kayıp yaşayan birey, bir sonraki işinde önceki işine kıyasla aynı geliri elde edememe durumu ortaya çıkacaktır. İkinci olarak, kaza sonrası iş arama sürecinde fiziksel yetersizliklerden dolayı işsiz kalma süresi artacak, bu durum evinin refah düzeyini etkileyecek ve ailenin dağılmasına kadar süreci götürebilecektir. En kötü ihtimalde de işçinin ölümü ile sonuçlanan bir kaza olacaktır. Bu durum bile çoğu zaman arkadasında kalan aileyi birçok faktör açısından yaralamaya devam 
edecektir. İşs sağlığı ve güvenliğine işçi açısından bakıldığında, ele alınması gereken en önemli başlık "eğitim"'dir. Çoğu zaman eğitim eksikliği ve dikkatsizlik sonucu meyadana gelen iş kazalarını azaltmanın ilk yöntemi çalışanlara verilen eğitim süresinin arttırılmasıdır. Eğitim ile birlikte bilinç düzeyi artan işçilerin tehlikeli davranışlardan kaçınma durumu artacak, sonucunda da daha sağlıklı bireyler olarak iş hayatında kalmaya devam edecekelerdir.(Bilir, 2016, s.18)

İşverenler açısından ise iş sağlığı ve güvenliği görünür ve görünmeyen birçok maliyeti ortaya çıkarmaktadır. İş sağlığı ve güvenliği, bir işletmenin tam performans ile çalışması ile ilişkilidir. Sağlık ve güvenlik açısından var olan çalışma ortamı, işçilerin tam performans ile çalışmalarını engelleyecek temel unsurların başında gelmektedir. Diğer taraftan da, bakımı yapılmayan makina ve teçhizat ürünleri ve iş kazası sonrası teknolojik ürünlerin bir süre kullanılamaması durumu işletme açısından birçok maliyeti ortaya çıkarmaktadır.

İş sağlığı ve güvenliğinin devlet açısından önemine bakıldığında ise; ekonomik ve sosyal açıdan ortaya çıkabilecek zararlar görülmektedir. İş kazaları ve meslek hastalıklarının artması, ekonomik açıdan işçi ve işverene olduğu kadar devlete de maliyet yüklemektedir. Ortaya çıkan sosyal güvenlik maliyetleri en önemli maliyet kalemi olarak görülmektedir. Dolaylı maliyetler arasında ise, iş kazası ve meslek hastalıklarının artmasından ötürü hastanelerde doluluk oranlarının artması sağlık hizmetinin performansını etkileycektir. Ölümle sonuçlanan iş kazalarının artması ise, ülkeleri uluslararası platformda nitelikli işgücünü ülkesine çekmesini engelleyen en önemli faktörler arasında yer alacaktır. Ek olarak da, yabancı sermayenin yatırımını etkileyerek büyüme ve kalkınmayı sekteye uğratacaktır.

\section{Örgütsel Bağlılık Kavramı ve Etkileyen Faktörler}

İşverenlerin kurumsal şirket yapısına doğru evrilmesiyle birlikte çalışanlar da profesyonel bakış açısına evrilmeye başladı. Bu yapı işletmeler açısından birçok yeni kazanım ortaya çıkarsa da bazı kayıpları da berberinde getirmektedir. Bu kayıpların başında, çalışanların bağlılığı yer almaktadır. Günümüzde şirket performansını etkileyen başlıca faktörler arasında yer alan çalışanların işletmeye olan bağlılığı, literatürde de ele alınmakta ve "örgütsel bağlılık" kavramı olarak kullanılmaktadır. Örgütsel bağlılık literatürde 
farklı tanımları mevcuttur. Saldamlı (2009)'ya göre örgütsel bağlılık; "Kişinin belirli bir örgüt ile girdiği kimlik birliği ve bağhllı̆̆ı birleşik gücüdür" Seymen (2008)'e göre tanımı ise; "İş görenlerin örgütün amaç ve hedeflerine güçlü bir inanç duymaları ve örgütün değer sistemi ile bütünleşmelerini içeren karmaşık bir sadakat duygusunu ifade eder." Doğan (2013)'a göre örgütsel bağlllık tanımı ise; "Bireyi örgüte bağlayan ve katılımını sağlayan bir güç olarak tanımlanmıştır. Literatürde yapılan bazı örgütsel davranış tanımlarına bakıldığında düşünce birliğinin olmadığı görülmektedir. Araştırmacılar yaptıkları araştırmalara zemin oluşturabilmesi için kavrama farklı anlamlar yükleyerek kavramın özünü genişletmeye çalıştıkları görülmektedir. Diğer taraftan Meyer ve Allen, örgütsel bağlılığın tanımının üç boyutta yapılması gerektiğine vurgu yapmaktadır. Buna göre; örgüte karşı duygusal yönetim, örgütten ayrılmanın getireceği maliyetlerin farkında olma ve örgütte kalmayı sağlayan bir manevi mecburiyet olarak görmek olarak üç grupta farklı tanımlamaktadır.(Akıncı ve Gül, 2007, s.142-143)

Örgütsel bağlılık, çalışanların aidiyet duygusunu arttırırken, örgüt ile bütünleşmesine zemin hazırlayan faktörleri kapsamaktadır. Literatürde yap1lan taramada genel olarak bu faktörler iki grupta ele alındığı görülmektedir. Bunlar; bireysel faktörler ve örgütsel faktörler olarak ele alınmaktadır. Yapılan çalışmalarda birçok bireysel faktör ile bireylerin örgütsel bağlılığı arasinda güçlü ilişkiler olduğu görülmektedir. Bireysel faktörlerden en belirgin etkinin bireylerin yaşı ile olduğu görülmektedir. Yapılan çalışmaların genelinde bireylerin yaşı ile örgütsel bağllıkları arasında doğru orantı tespit edilmiştir. Diğer bir ifadeyle, çalışanların yaşı arttıkça örgütsel bağllıklarının arttı̆̆ görülmektedir.(İnce ve Gül, 2005, s.28) Diğer bireysel faktör olarak, medeni durumun örgütsel bağlllık üzerinde yüksek oranda etkisi olduğu görülmüştür. Yabancı literatürde yapılan çalışmalarda evli çalışanların, bekâr çalışanlara göre örgüte karşı daha fazla bağlılık hissettikleri görülmüştür.(Kargar, 2012, s. 5018) Diğer bir bireysel faktör de eğitim durumudur. Yurtiçi ve yurtdışında yapılan birçok çalışmada, bireylerin eğitimleri arttıkça geniş iş imkanlarına sahip olmalarına nedeniyle örgütsel bağlllıklarının azaldığı tespit edilmiştir.(Khan, 2011, s.118) Örgütsel bağlılığ1 etkileyen son bireysel faktör ise çalışma süresidir. Yapılan çalışmaların genelinde bireylerin çalışma süresi ile birlikte hizmet süresi arttıkça örgütten elde ettiği kazancının da artacağı, bu geliri kaybetmek istemeyen çalışanların da çalıştıkları örgüte daha fazla bağlanacakları görülmüştür. (Gül, 2016, s.44) 
Örgütsel faktörler ise; işin niteliği, ücret düzeyi, çalışma sisteminde esneklik, örgütsel kültür ve örgütsel ödüller olarak ifade edilmektedir. (İnce ve Gül, 2005, s. 71-76)

\section{Konuya İlişkin Bir Alan Araştırması}

Konu ile ilgili yaptığımız alan çalışmasına geçmeden önce; örgütsel bağlılık ile iş sağlığı ve güvenliği konularının ilişkilendirildiği gerek yerli gerekse de yabancı literatürde fazla çalışması olmadığı görülmektedir. Yapılan çalışmalar kısaca göz atıldığında birbirine benzer bulgular ortaya koyulduğu görülmektedir. Kılıç ve Selvi (2009), Omusulah (2013), Gyekye (2015), Amponsah(2016), Çınar ve Gündoğdu (2019) tarafından gerçekleştirilen çalışmalar, iş sağlığı ve güvenliği anlayışının işletmede gelişmesi ile örgütsel bağlllı̆ı̆n artması yönünde pozitif yönlü bir ilişki olduğu ifade edilmektedir. Bu kapsamda yapılan çalışmalar ışında çalışmanın sonuçlarının benzerlik gösterip göstermeyeceği de kapsamlı şekilde incelenecektir.

\section{Araştırmanın Amacı}

İş sağlığı ve güvenliği her geçen önemini arttırarak, gelişmiş ve gelişmekte olan ülkelerin kalkınma düzeylerinin bir belirleyicisi haline dönüşmüştür. Çalışanlar için iş sağlığı ve güvenliği uygulamalarının gerçekleştirildiği işyerleri bir tatmin kaynağıdır. İş sağlığı ve güvenliği uygulamalarının tam olarak uygulandığı iş yerlerinde çalışanlar, kendilerine değer verildiği duygusu ile örgüte olan bağlıklarını arttırırlar. Örgüte bağlllık gösteren çalışanların, aynı zamanda yüksek düzeyde üretken oldukları; sadakat, verimlilik ve sorumluluk duygusuyla hareket ettikleri görülmektedir. İs sağlığı ve güvenliğinden yoksun çalışanlar, emniyet ve güvenlik duygusundan da yoksun olacağından dolayı bir hoşnutsuzluk içine girerleri, işyerine ve işlerine karşı olumsuz tutumlar geliştirirler. İşlerine karşı olumsuz tutum geliştirenlerin aynı zamanda örgüte olan bağllı̆̆g da ortadan kalkmaktadır. Örgütsel bağlılı̆̆ı azalan çalışan için işe geç gelme, devamsızlık yapma, işe yabancılaşma ve işten ayrılma gibi sonuçları ortaya çıkmaktadır.

Bu çalışmanın temel amacı, iş sağlığı ve güvenliği uygulamalarının örgütsel bağlılığa olan yansımalarını incelemektir. Araştırmada, çalışanların iş sağlığı ve güvenliği algı düzeyi ile örgütsel bağlılık düzeyi arasında varsa 
ilişkiler, yönleri ve düzeyleri tespit edilmeye çalışılmıştır. Araştırmada kullanılan veriler, belli bir zamanda anket formları ile çalışanlardan toplanmış ve değişkenler arasında ilişki olup olmadığı araştıılmıştır.

\section{Araştırmanın Hipotezleri}

Araştırma problemine uygun olarak nicel araştırma bölümünün ana ve alt hipotezleri aşağıdaki gibidir.

\section{Ana Hipotez-Alt Hipotezler:}

- Hı:Çalışanların iş sağlığı ve güvenliği algı düzeyleri ile örgütsel bağlılık düzeyi arasında anlamlı bir ilişki vardır.

- H1-a:Çalışanların iş sağlığı ve güvenliği algı düzeyleri ile duygusal bağlılık düzeyi arasında anlamlı bir ilişki vardır.

- H-b:Çalışanların iş sağlı̆̆ı ve güvenliği algı düzeyleri ile normatif bağlılık düzeyi arasında anlamlı bir ilişki vardır.

- H1-c:Çalışanların iş sağlığı ve güvenliği algı düzeyleri ile devamlılık bağlılık düzeyi arasında anlamlı bir ilişki vardır.

\section{Alt Hipotezler:}

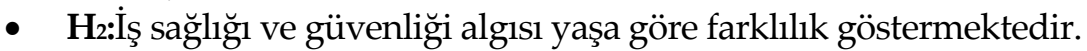

- $\quad \mathbf{H}_{3}:$ Örgütsel bağlllık düzeyi yaşa göre farklılık göstermektedir.

- H: H:Şs sağlığı ve güvenliği algısı eğitim durumuna göre farklılık göstermektedir.

- H5:Örgütsel bağlllık düzeyi eğitim durumuna göre farklılık göstermektedir.

- H6: İs sağlığı ve güvenliği algısı çalışma süresi durumuna göre farkl1lik göstermektedir.

- $\quad \mathbf{H}_{7}:$ Örgütsel bağlılık düzeyi çalışma süresi durumuna göre farklılık göstermektedir.

\section{Araştırmanın Yöntemi}

Çalışmamızda nicel araştırma yöntemi tercih edilmiştir. "Nicel araştırma yöntemleri, ampirik veya sayısal yaklaşım şeklinde de adlandırılmaktadır. Nicel araştırma yönteminde araştırılmak istenen konu ile ilgili evreni temsil 
eden bir örneklem üzerinden sayısal veriler elde edilir. Elde edilen sayısal veriler üzerinden yorum ve genellemeler yapılır. Nicel araştırmada değişkenler arasındaki ilişkiler kanıtlanmaya çalışılır ve bu ilişkilerin nedenleri araştırılır."(Özdemir, 2011, s.55)

Nicel yaklaşım doğrultusunda gerçekleştirilen çalışmamızda sayısal verilere ulaşmak için anket formları kullanılmıştır. Anket formu aracılığı ile çalışanların işyerindeki iş sağlığı ve güvenliği uygulamalarına yönelik düşüncelerine, örgütsel güven ve bağlllıklarına yönelik veriler elde edilmiştir.

\section{Evren ve Örneklem}

Araştırmanın evreni, İstanbul'da faaliyet gösteren bir çevre yönetimi şirketi çalışanlarından oluşmaktadır. Personel müdürlüğünden gerekli izinler alındıktan sonra, anket formları kurum personeline bire bir görüşme suretiyle teslim edilip, uygulama amacı hakkında kısaca bilgi verildikten sonra doldurulmuştur. Araştırmada örnek olarak seçilen Saha Hizmetleri Müdürlüğü bünyesinde aktif olarak görev yapan 130 personele birim ya da ünvan ayrımı gözetilmeksizin toplam olarak 130 adet anket formu dağıtılmış ve dağıtılan anketlerin tümü değerlendirmeye tabi tutulmuştur. Anket verileri analiz edilerek, belirlenen bulguların bilimsel açıdan sağlıklı bir biçimde yorumlanması ve etkin sonuçlar elde edilmesi hedeflenmiştir.

\section{Veri Toplama Tekniği}

Araştırmada veri toplama aracı olarak kullanılan anket formu 09-16 Ekim 2017 tarihlerinde çalışma saatleri arasında ve işi aksatmayacak şekilde, katılımcılara ön açıklama ve bilgilendirme yapılması sonrası gönüllü olarak sorulara cevap vermeleri suretiyle gerçekleştirilmiştir. Anket her bir katılımcı ile yüz yüze görüşme yöntemi kullanılarak yapılmıştır. Anketin güvenilirliğini artırmak için, katılan işçilerin kimlikleri gizli tutulmuş ve anket formuna isimleri yazılmamıştır.

Araştırmanın veri toplama yöntemi üç bölümden oluşmaktadır. Birinci bölümde öncelikle demografik özelliklere, cinsiyet, yaş, medeni durum, öğrenim durumu, şirketteki görevi, çalışma süresi ve aylık gelire yönelik 7 adet soruya yer verilmiştir. 
Araştırmanın ikinci bölümünde Saha Hizmetleri Müdürlüğü bünyesinde aktif olarak görev yapan çalışanların iş sağlığı ve güvenliği uygulamalarına yönelik olan 10 adet soruya yer verilmiştir. Anket formunda yer alan önermeler için $5^{\text {e }}$ li likert tipi ölçek kullanılmış ve her bir önermede, Hiç katılmıyorum, Katılmiyorum, Fikrim yok, Katıliyorum, Tamamen katılıyorum şeklinde derecelendirilmiş cevaplara yer verilmiştir.

Araştırmanın üçüncü ve son bölümünde Saha Hizmetleri Müdürlüğü bünyesinde aktif olarak görev yapan çalışanların örgütsel bağlllı̆̆a yönelik olan 10 adet soruya yer verilmiştir. Anket formunda yer alan önermeler için

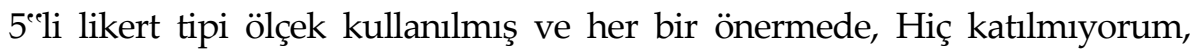
Katılmıyorum, Fikrim yok, Katılıyorum, Tamamen katılıyorum şeklinde derecelendirilmiş cevaplara yer verilmiştir.

\section{Verilerin Çözümlenmesi}

Araştırma için gerekli veriler, çalışanlara uygulanan anket yoluyla elde edilmiş ve bilgisayara aktarılmıştır. SPSS 22.0 (Statistical Package for The Social Science) programından yararlanılmıştır. Hipotezlerin test edilmesi aşamasında korelasyon analizi, bağımsız örneklem $\mathrm{T}$ testi ve varyans analizi uygulanarak, frekans, yüzde, ortalama, standart sapma değerleri hesaplanmış ve tablo yöntemi ile çalışmada sunulmuştur.

\section{Araştırmanın Bulgular}

\section{1. Çalışanların Demografik Özelliklerine İlişkin Bulgular}

Demografik bulgular başlığı altında incelenecek konular, anket çalışmasına katılan çalışanların cinsiyet, yaş, medeni durum, eğitim durumu, iş ve görevleri, şirketteki çalışma süreleri ve aylık gelir düzeylerine göre dağılımları ve sayılarıdır.

Tablo- 1 : Demografik Faktörlere Ait Bulgular

\begin{tabular}{lll}
\hline Cinsiyet & $\mathbf{n}$ & $\mathbf{\%}$ \\
\hline Kadın & 4 & 3,08 \\
Erkek & 126 & 96,92 \\
Toplam & 130 & 100 \\
\hline Yaş & $\mathbf{n}$ & $\mathbf{\%}$ \\
\hline
\end{tabular}




\begin{tabular}{|c|c|c|}
\hline $18-25$ & 10 & 7,7 \\
\hline $26-33$ & 29 & 22,3 \\
\hline $33-40$ & 57 & 43,85 \\
\hline 41 ve üzeri & 34 & 26,15 \\
\hline Toplam & 130 & 100 \\
\hline Medeni Durumu & $\mathbf{n}$ & $\%$ \\
\hline Bekâr & 23 & 17,7 \\
\hline Evli & 107 & 82,3 \\
\hline Toplam & 130 & 100 \\
\hline Eğitim Durumu & $\mathbf{n}$ & $\%$ \\
\hline İlköğretim & 23 & 17,8 \\
\hline Ortaöğretim & 54 & 41,6 \\
\hline Meslek Yüksekokulu & 35 & 26,7 \\
\hline Üniversite & 18 & 13,9 \\
\hline Toplam & 130 & 100 \\
\hline Görevi & $\mathrm{n}$ & $\%$ \\
\hline Beden İşçisi & 71 & 54,62 \\
\hline Şöför & 22 & 16,92 \\
\hline Tekniker & 9 & 6,92 \\
\hline Teknisyen & 17 & 13,08 \\
\hline Operatör & 5 & 3,85 \\
\hline Formen & 2 & 1,53 \\
\hline Kimyager & 4 & 3,08 \\
\hline Toplam & 130 & 100 \\
\hline Çalışma Süresi & $\mathbf{n}$ & $\%$ \\
\hline $0-3 Y_{11}$ & 23 & 17,7 \\
\hline 3-6 Y 11 & 29 & 22,3 \\
\hline 6-9 Yil & 41 & 31,53 \\
\hline 9-12 Yil & 22 & 16,92 \\
\hline 13 Yıl ve Üzeri & 15 & 11,55 \\
\hline Toplam & 130 & 100 \\
\hline
\end{tabular}

Tablo-1'de görüldüğü üzere ankete katılan çalışanların \%96,62'sini (n=126) erkekler, \%3.08'sını $(n=4)$ kadınlar oluşturmaktadır. Araştırmaya katılanlanların genelini erkek bireyler oluşturduğu görülmektedir. Diğer taraftan, ankete katılan çalışanların \%7,70'i ( $\mathrm{n}=10)$ 18-25, \%22,30'u ( $\mathrm{n}=29)$ 26-33, $\% 43,85$ 'i (n=57) 33-40 ve \%26,15'i (n=34) 41 ve üzeri yaş aralığındadır. Çalışanların çoğunluğu $(n=57) 33-40$ yaş aralığında olduğu belilenmiştir. Ek olarak, ankete katılan çalışanların \%17,70'i (n=23) bekâr, \%82,30'u (n=107) evlidir. Çalışanların çoğunluğu $(n=107)$ evli kişilerdir. Eğitim durumlarına bakıldığında ise, \%17,80'i (n=23) İlköğretim, \%41,60'1 (n=54) Ortaöğretim, \%26,70'i (n=35) Meslek Yüksek Okulu ve \%13,90'1 (n=18) Üniversite mezunudur. Çalışanların çoğunluğu $(n=54)$ Ortaöğretim mezunudur. Meslek gruplarına göre ise; ankete katılan çalışanların \%54,62'si (n=71), Beden İşçisi, 
\%16,92'si (n=22) Şoför, \%6,92'si (n=9) Tekniker, \%13,08’1 (n=17) Teknisyen, \%3,85'i (n=5) Operatör, \%1,53'ü (n=2) Formen, \%3,08'i (n=4) Kimyager olarak görev yapmaktadır. Çalışanların çoğunluğu $(n=71)$ Beden işçisidir. K1dem süreleri dikkate alındığında ise; ankete katılan çalışanların \%17,70'i (n=23) 0-3 Yil, \%22,30'u (n=29) 3-6 Y1l, \%31,53'ü (n=41) 6-9 Y1l, \%16,92'si (n=22) 9-12 Yıl, \%11,55’i (n=15kişi) 13 Yıl ve üzeri aynı şirkette çalıştıklarını belirtmişlerdir. Çalışanların çoğunluğu (n=41) 6-9 yıldır aynı şirkette çalışmaktadır.

\section{2. İş Sağlı̆̆ı ve Güvenliği Algı Düzeylerine İlişkin Bulgular}

Araştırmanın bu bölümünde İş sağlığı ve güvenliği ölçeğinde yer alan her bir soruya yönelik çalışan görüşleri frekans dağılımları ve tanımlayıcı istatistikler yardımı ile belirlenmiştir.

Tablo 2. İş Kazaları Oranlarının Azaltılması Hakkındaki Düşünceler

\begin{tabular}{|c|c|c|c|c|}
\hline & Gruplar & $\begin{array}{l}\text { Frekans } \\
\text { (n) }\end{array}$ & Yüzde\% & $\begin{array}{l}\text { Kümülâtif } \\
\%\end{array}$ \\
\hline 1-Çalıştığım şirket & Hiç Katılmıyorum & 7 & $5 \%$ & 5 \\
\hline iş kazaları oranlarını & Katılmiyorum & 8 & $6 \%$ & 11 \\
\hline azaltmada çalışanların & Fikrim Yok & 19 & $14 \%$ & 25 \\
\hline katılımını iş sağlı̆̆ı ve & Katıliyorum & 54 & $41 \%$ & 66 \\
\hline güvenliğinin temeli olarak & Tamamen Katılıyorum & 42 & $34 \%$ & 100 \\
\hline görmektedir. & Toplam & 130 & $100 \%$ & \\
\hline
\end{tabular}

Ankete katılan çalışanların "Çalıştı̆̆ım şirket iş kazaları oranlarını azaltmada çalışanların katılımını iş sağlı̆̆ı ve güvenliğinin temeli olarak görmektedir" değişkenine göre verdiği cevaplar incelendiğinde; çalışanların yaklaşık \%75'i katılıyorum, \% 11'i katılmadığ 1 cevabını verirken \%14'ü fikri olmadığını belirtmiştir.

Tablo 3. Şirket ve Yöneticilerinin İş Sağlığı ve Güvenliği Konularındaki Duyarlılığı Hakkındaki Düşünceler

\begin{tabular}{|c|c|c|c|c|}
\hline & Gruplar & Frekans(n) & Yüzde\% & Kümülâtif \% \\
\hline Çalıştığım şirket ve & Hiç Katılmıyorum & 10 & $8 \%$ & 8 \\
\hline yöneticilerim kalite ve & Katılmiyorum & 18 & $14 \%$ & 22 \\
\hline verimlilik & Fikrim Yok & 27 & $21 \%$ & 43 \\
\hline kadar iş sağlı̆̆ 1 ve & Katıliyorum & 31 & $23 \%$ & 66 \\
\hline güvenliği konularında & Tamamen Katılıyorum & 44 & $34 \%$ & 100 \\
\hline da duyarlıdır. & Toplam & 130 & $100 \%$ & \\
\hline
\end{tabular}


Ankete katılan çalışanların "Çalıştığım şirket ve yöneticilerim kalite ve verimlilik konuları kadar iş sağlığı ve güvenliği konularında da duyarlıdır." değişkenine göre verdiği cevaplar incelendiğinde; çalışanların yaklaşık \%57'i katılıyorum, \% 22'si katılmadığı cevabını verirken \%21'İ fikri olmadığını belirtmiştir.

Tablo 4. Şirketin Çalışan Să̆lı̆̆ı ve Güvenliğine Bakışı Hakkındaki Düşünceler

\begin{tabular}{llccc}
\hline & Gruplar & Frekans $(\mathbf{n})$ & Yüzde\% & Kümülâtif \% \\
\hline Çalıştı̆̆ım & Hiç Katılmıyorum & 8 & $6 \%$ & 6 \\
şirkette çalışanların & Katılmıyorum & 12 & $9 \%$ & 15 \\
sağlığı ve güvenliği & Fikrim Yok & 32 & $25 \%$ & 40 \\
öncelik taşımaktadır. & Katıllyorum & 26 & $20 \%$ & 60 \\
& Tamamen Katılıyorum & 52 & $40 \%$ & 100 \\
& Toplam & 130 & $100 \%$ & \\
\hline
\end{tabular}

Ankete katılan çalışanların "Çalıştı̆̆ım şirkette çalışanların sağlığı ve güvenliği öncelik taşımaktadır." değişkenine göre verdiği cevaplar incelendiğinde; çalışanların yaklaşık \%60'ı katılıyorum, \% 15'i katılmadığı cevabını verirken $\% 25$ 'i fikri olmadığını belirtmiştir.

Tablo 5. İş Sağliğı ve Güvenliği Ĕgitimi Hakkındaki Düşünceler

\begin{tabular}{llccc}
\hline & Gruplar & Frekans (n) & Yüzde\% & Kümülâtif \% \\
\hline Çalıştı̆̆ım şirkette & Hiç Katılmıorum & 10 & $8 \%$ & 8 \\
sık güvenlik & Katılmıyorum & 13 & $10 \%$ & 18 \\
eğitimi aldığımdan & Fikrim Yok & 25 & $19 \%$ & 37 \\
dolayı daha güvenli & Katılıyorum & 33 & $25 \%$ & 62 \\
çalışıyorum. & Tamamen Katıllyorum & 49 & $38 \%$ & 100 \\
& Toplam & 130 & $100 \%$ & \\
\hline
\end{tabular}

Ankete katılan çalışanların "Çalıştığım şirkette sık güvenlik eğitimi aldığımdan dolayı daha güvenli çalışıyorum." değişkenine verdiği cevaplar incelendiğinde; çalışanların yaklaşık \%63'ü katılıyorum, \% 18'i katılmadığı cevabını verirken \%19'ü fikri olmadığını belirtmiştir.

Tablo 6. İş Kazaları Hakkındaki Düşünceler

\begin{tabular}{llccc}
\hline & Gruplar & Frekans $(\mathbf{n})$ & Yüzde\% & Kümülâtif \% \\
\hline Çalıştı̆ım şirketin tüm & Hiç Katılmıyorum & 28 & $21 \%$ & 21 \\
çabalarına & Katılmıyorum & 24 & $18 \%$ & 39 \\
rağmen & Fikrim Yok & 9 & $7 \%$ & 46 \\
kazaları̈n önlenmesi & Katılıyorum & 31 & $24 \%$ & 70 \\
mümkün değildir. & Tamamen Katıllyorum & 38 & $30 \%$ & 100 \\
& Toplam & 130 & $100 \%$ & \\
\hline
\end{tabular}


Ankete katılan çalışanların "Çalıştığım şirketin tüm çabalarına rağmen kazaların önlenmesi mümkün değildir." değişkenine verdiği cevaplar incelendiğinde; çalışanların yaklaşık \%54'ü katılıyorum, \% 39'u katılmadığı cevabını verirken \% $\%$ 'si fikri olmadığını belirtmiştir.

Tablo 7. İş Sağlığı ve Güvenliği Kural ve Prosedürleri Hakkındaki Düşünceler

\begin{tabular}{|c|c|c|c|c|}
\hline & Gruplar & Frekans (n) & Yüzde\% & Kümülâtif \% \\
\hline \multirow{6}{*}{$\begin{array}{l}\text { Çalıştığım şirkette } \\
\text { alınan tüm güvenlik } \\
\text { kuralları ve prosedür- } \\
\text { leri gerçekten } \\
\text { işe yarıyor. }\end{array}$} & Hiç Katılmıyorum & 12 & $9 \%$ & 9 \\
\hline & Katılmiyorum & 15 & $11 \%$ & 20 \\
\hline & Fikrim Yok & 10 & $7 \%$ & 27 \\
\hline & Katıliyorum & 45 & $34 \%$ & 61 \\
\hline & Tamamen Katılıyorum & 48 & $39 \%$ & 100 \\
\hline & Toplam & 130 & $100 \%$ & \\
\hline
\end{tabular}

Ankete katılan çalışanların "Çalıştığım şirkette alınan tüm güvenlik kuralları ve prosedürleri gerçekten işe yarıyor." değişkenine verdiği cevaplar incelendiğinde; çalışanların yaklaşık \%73'ü katılıyorum, \%20'i katılmadığı cevabını verirken $\% 7^{\prime}$ si fikri olmadığını belirtmiştir.

Tablo 8. İş Sağlı̆̆ı ve Güvenliği Ekipmanlarını Kullanma Hakkında Düşünceler

\begin{tabular}{llccc}
\hline & Gruplar & Frekans $(\mathbf{n})$ & Yüzde\% & Kümülâtif \% \\
\hline İşimi & Hiç Katılmıyorum & 3 & $2 \%$ & 2 \\
yaptığım esnada & Katılmıyorum & 10 & $7 \%$ & 9 \\
bütün & Fikrim Yok & 0 & $0 \%$ & 9 \\
gerekli güvenlik & Katılıyorum & 63 & $48 \%$ & 57 \\
ekipmanlarını & Tamamen Katılıyorum & 54 & $43 \%$ & 100 \\
kullanırım. & Toplam & 130 & $100 \%$ & \\
\hline
\end{tabular}

Ankete katılan çalışanların "İşimi yaptığım esnada bütün gerekli güvenlik ekipmanlarını kullanırım." değişkenine verdiği cevaplar incelendiğinde; çalışanların yaklaşık \%91'i katılıyorum, \%9'u katılmadığı cevabını vermiştir.

Tablo 9. İş Kazası Sonrası Maddi ve Manevi Tazminat Hakkındaki Düşünceler

\begin{tabular}{llccc}
\hline & Gruplar & Frekans $(\mathbf{n})$ & Yüzde\% & Kümülâtif \% \\
\hline İş kazasında & Hiç Katılmıyorum & 3 & $3 \%$ & 3 \\
işverenden maddi & Katılııyorum & 5 & $4 \%$ & 7 \\
ve manevi tazminat & Fikrim Yok & 0 & $0 \%$ & 7 \\
alma hakkımın & Katıllyorum & 24 & $18 \%$ & 25 \\
olduğunu & Tamamen Katıllyorum & 98 & $75 \%$ & 100 \\
biliyorum. & Toplam & 130 & $100 \%$ & \\
\hline
\end{tabular}


Ankete katılan çalışanların "İş kazasında işverenden maddi ve manevi tazminat alma hakkımın olduğunu biliyorum." değişkenine verdiği cevaplar incelendiğinde; çalışanların yaklaşık \%93'ü katılıyorum, \%7'si katılmadığı cevabını vermiştir.

Tablo 10. İş Sağlı̆̆ı ve Güvenliği Kurallarına Uymak

\begin{tabular}{lllll}
\hline & Gruplar & Frekans (n) & Yüzde\% & Kümülâtif \% \\
\hline Çalıştı̆ı̆ şirkette & Hiç Katılmıyorum & 0 & $0 \%$ & 0 \\
iş sağlığı ve & Katılmıyorum & 0 & $0 \%$ & 0 \\
güvenliği kurallarına & Fikrim Yok & 8 & $6 \%$ & 6 \\
daima uyuyorum. & Katılıyorum & 43 & $33 \%$ & 39 \\
& Tamamen Katıllyorum & 79 & $61 \%$ & 100 \\
& Toplam & 130 & $100 \%$ & \\
\hline
\end{tabular}

Ankete katılan çalışanların "Çalışttğım şirkette iş sağlığı ve güvenliği kurallarına daima uyuyorum." değişkenine verdiği cevaplar incelendiğinde; çalışanların yaklaşık \%94'ü katılıyorum, \%6'sı fikrim yok cevabını vermiştir.

Tablo 11. İş Să̆lı̆̆ı ve Güvenliği Uygulamalarının Çalışanlara Verilen Değerle Olan İlişkisi

\begin{tabular}{llccc}
\hline & Gruplar & Frekans(n) & Yüzde\% & Kümülâtif \% \\
\hline Çalıştığım & Hiç Katılmıyorum & 9 & $7 \%$ & 7 \\
şirkette uygulanan & Katılmıyorum & 11 & $8 \%$ & 15 \\
iş sağlığ & Fikrim Yok & 4 & $3 \%$ & 18 \\
ve güvenliği sistemi & Katıliyorum & 62 & $48 \%$ & 66 \\
çalışanlara verilen & Tamamen Katılıyorum & 44 & $34 \%$ & 100 \\
değerin göstergesidir. & Toplam & 130 & $100 \%$ & \\
\hline
\end{tabular}

Ankete katılan çalışanların "Çalıştığım şirkette uygulanan iş sağlığı ve güvenliği sistemi çalışanlara verilen değerin göstergesidir." değişkenine verdiği cevaplar incelendiğinde; çalışanların yaklaşık \%82'si katılıyorum, \% 15'i katılmadığı cevabını verirken \%3'ü fikri olmadığını belirtmiştir.

Ayrıca iş sağlığı ve güvenliği ölçeğinin tanımlayıc istatistikleri incelendiğinde, örneklemi oluşturan katılımcıların en çok katıldıkları maddeler şunlardır;

- İşimi yaptığım esnada bütün gerekli güvenlik ekipmanlarını kullanırım.

- İş kazasında işverenden maddi ve manevi tazminat alma hakkımın olduğunu biliyorum.

- Çalıştığım şirkette iş sağlığı ve güvenliği kurallarına daima uyuyorum. 
- Çalıştığım şirkette uygulanan iş sağlığı ve güvenliği sistemi çalışanlara verilen değerin göstergesidir

Veri toplama aracının ikinci bölümünde Ekici (2003) tarafından geliştirilen ihtiyaç analizi ölçeği esas alınarak, İş sağlığı ve güvenliği ölçeğinde yer alan maddelere ilişkin değerlendirmede 5'li likert ölçeği kullanılmıştır. Sorulara en düşük 1 , en yüksek 5 puan verilmiş ve değişim aralığ 4 olarak hesaplanmıştır. Bu durumda derecelendirme için sinıf aralığ $4 / 5=0,80$ olarak elde edilmiştir. Bu durumda ilgili sınıflandırma şu şekildedir;

$1.00-1.80=$ Ç̧ok düşük düzeyde iş sağllğı ve güvenliği algısı.

$1.81-2.60=$ Düşük düzeyde iş sağllğı ve güvenliği algısı.

$2.61-3.40=$ Orta düzeyde iş sağlığı ve güvenliği algisı.

$3.41-4.20=$ Yüksek düzeyde iş sağllğ 1 ve güvenliği algısı.

$4.21-5.00=$ Çok yüksek düzeyde iş sağlığ ve güvenliği algısı.

Tablo 12. İş Să̆hl̆̆̆ ve Güvenliği Ölçeğine İlişkin Betimsel İstatistikler

\begin{tabular}{|c|c|c|}
\hline & $\overline{\mathbf{X}}$ & Std. Sapma \\
\hline $\begin{array}{l}\text { Çalıştı̆ıım şirket iş kazaları oranlarını azaltmada çalışanların katılımını iş sağlığı ve } \\
\text { güvenliğinin temeli olarak görmektedir. }\end{array}$ & 4,722 & 0,458 \\
\hline $\begin{array}{l}\text { Çalıştığım şirket ve yöneticilerim kalite ve verimlilik konuları kadar işs sağlığı ve } \\
\text { güvenliği konularında da duyarlıdır. }\end{array}$ & 3,500 & 1,116 \\
\hline Çalıştığım şirkette çalışanların sağlığı ve güvenliği öncelik taşımaktadır. & 4,177 & 0,997 \\
\hline Çalıştı̆ıım şirkette sık güvenlik eğitimi aldığımdan dolayı daha güvenli çalışıyorum. & 4,150 & 0,822 \\
\hline Çalıştığım şirketin tüm çabalarına rağmen kazaların önlenmesi mümkün değildir. & 3,377 & 1,037 \\
\hline Çalıştı̆ı̆ şirkette alınan tüm güvenlik kuralları ve prosedürleri gerçekten işe yarıyor. & 4,609 & 0,533 \\
\hline İşimi yaptığım esnada bütün gerekli güvenlik ekipmanlarını kullanırım. & 4,672 & 0,489 \\
\hline 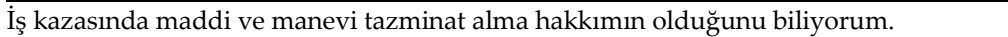 & 4,695 & 0,461 \\
\hline Çalıștığım şirkette iş sağlığı ve güvenliği kurallarına daima uyuyorum. & 4,781 & 0,413 \\
\hline $\begin{array}{l}\text { Çalıştı̆̆ım şirkette uygulanan iş sağlığı ve güvenliği sistemi çalışanlara verilen } \\
\text { değerin göstergesidir. }\end{array}$ & 4,931 & 0,252 \\
\hline Genel & 4,361 & 0,657 \\
\hline
\end{tabular}

Sonuç olarak; İş sağllğı ve güvenliği ölçeğine ilişkin genel ortalama incelendiğinde, skorun çok yüksek düzeye denk geldiği gözlenmiştir yani çal1şanların iş sağlığı ve güvenliğine yönelik algılarının çok yüksek düzeyde olduğu saptanmıştır. 


\section{3. Örgütsel Bağhlıkk Algı Düzeylerine İlişkin Bulgular}

Araştırmanın bu bölümünde örgütsel bağlllık ölçeğinde yer alan her bir soruya yönelik çalışan görüşleri frekans dağılımları ve tanımlayıcı istatistikler yardımı ile belirlenmiştir.

Tablo 13. Çalışma Arkadaşlan Hakkındaki Düşünceler

\begin{tabular}{|c|c|c|c|c|}
\hline & Gruplar & Frekans(n) & Yüzde\% & Kümülâtif \% \\
\hline \multirow{6}{*}{$\begin{array}{l}\text { Çalıştığım şirkette } \\
\text { arkadaşlarımla } \\
\text { olan ilişkilerimden } \\
\text { memnunum. }\end{array}$} & Hiç Katılmıyorum & 8 & $6 \%$ & 6 \\
\hline & Katılmiyorum & 23 & $18 \%$ & 24 \\
\hline & Fikrim Yok & 34 & $26 \%$ & 50 \\
\hline & Katılıyorum & 46 & $35 \%$ & 85 \\
\hline & Tamamen Katılıyorum & 19 & $15 \%$ & 100 \\
\hline & Toplam & 130 & $100 \%$ & \\
\hline
\end{tabular}

Ankete katılan çalışanların "Çalıştı̆̆ım şirkette arkadaşlarımla olan ilişkilerimden memnunum." değişkenine verdiği cevaplar incelendiğinde; çallşanların yaklaşık \%35'i katılıyorum, \% 26'sı fikrim yok ,\%18'i katılmıyorum, \% 15'i tamamen katıliyorum ve \%6'sı hiç katılmıyorum cevabı belirtmiştir. Çalışanların birbirleri ile olan ilişkileri örgütsel bağlığı arttırmaktadır ve çalışanların bu şekilde düşünmemesi duygusal bağlllık derecesini düşürmektedir.

Tablo 14. Şirket İçi Kariyer Hakkındaki Düşünceler

\begin{tabular}{llccc}
\hline & Gruplar & Frekans (n) & Yüzde\% & Kümülâtif \% \\
\hline Kariyerimin & Hiç Katılmıyorum & 11 & $8 \%$ & 8 \\
kalan kısmını bu & Katılmıyorum & 28 & $21 \%$ & 29 \\
şirkette & Fikrim Yok & 9 & $7 \%$ & 36 \\
geçirmekten çok & Katılıyorum & 48 & $39 \%$ & 75 \\
mutlu olurum. & Tamamen Katıliyorum & 34 & $25 \%$ & 100 \\
& Toplam & 130 & $100 \%$ & \\
\hline
\end{tabular}

Ankete katılan çalışanların "Kariyerimin kalan kısmını bu şirkette geçirmekten mutlu olurum" değişkenine verdiği cevapları incelediğimizde, çalışanların \%39'u katılıyorum, \%25'i tamamen katılıyorum cevabı vermiştir. Çalışanların \%64'ü için duygusal bağlılık düzeylerinin olumlu olduğunu görmekteyiz. 
Tablo 15. Çalışanların Şirkete Olan Aidiyet Duyguları Hakkındaki Düşünceleri

\begin{tabular}{llccc}
\hline & Gruplar & Frekans (n) & Yüzde\% & Kümülâtif \% \\
\hline Çalıştığım şirkette, & Hiç Katılmıorum & 14 & $10,5 \%$ & 11 \\
kendimi “aileden biri” & Katılmiyorum & 26 & $20 \%$ & 31 \\
gibi hissediyorum. & Fikrim Yok & 3 & $2 \%$ & 33 \\
& Katılıyorum & 51 & $39 \%$ & 72 \\
& Tamamen Katılıyorum & 36 & $28,5 \%$ & 100 \\
& Toplam & 130 & $100 \%$ & \\
\hline
\end{tabular}

Ankete katılan çalışanların "Çalıştığım şirkette kendimi aileden biri gibi hissediyorum" değişkenine verdiği cevapları incelediğimizde, çalışanların \%39'u katılıyorum, \%28,5 tamamen katılıyorum cevabı vermiştir. Çalışanların \%67,5 kendilerini şirketin bir parçası olarak görmektedir. Bu sonuç çalışanların duygusal bağlılık düzeylerinin yüksek olduğunu göstermektedir.

Tablo 16. Şirkete Olan Bağlılık Hakkındaki Düşünceleri

\begin{tabular}{llccc}
\hline & Gruplar & Frekans (n) & Yüzde\% & Kümülâtif \% \\
\hline Çalışanların & Hiç Katılmıyorum & 8 & $6 \%$ & 6 \\
şirketlerine & Katılmıyorum & 12 & $9 \%$ & 15 \\
her zaman & Fikrim Yok & 22 & $17 \%$ & 32 \\
bağlı olmaları & Katılıyorum & 53 & $40 \%$ & 72 \\
gerektiğine & Tamamen Katılıyorum & 35 & $28 \%$ & 100 \\
inaniyorum. & Toplam & 130 & $100 \%$ & \\
\hline
\end{tabular}

Ankete katılan çalışanların "Çalışanların şirketlerine her zaman bağlı olmaları gerektiğine inanıyorum" değişkenine verdiği cevapları incelediğimizde, çalışanların \%40'1 katılıyorum, \%28'i tamamen katılıyorum cevabı vermiştir. Çalışanların \%68'i şirketlerine her zaman bağlı olmaya inanmaktadır. Bu sonuç çalışanların normatif bağlılık düzeylerinin yüksek olduğunu göstermektedir.

Tablo 17. Şirkette Kalmak İstek mi, Gereklilik mi?

\begin{tabular}{llccc}
\hline & Gruplar & Frekans (n) & Yüzde\% & Kümülâtif \% \\
\hline Şu anda şirkette & Hiç Katılmıyorum & 29 & $22 \%$ & 22 \\
kalmak benim için & Katılmıyorum & 33 & $25 \%$ & 47 \\
bir istekten çok bir & Fikrim Yok & 26 & $20 \%$ & 67 \\
gerekliliktir. & Katıliyorum & 18 & $13,5 \%$ & 81 \\
& Tamamen Katıllyorum & 24 & $19,5 \%$ & 100 \\
& Toplam & 130 & $100 \%$ & \\
\hline
\end{tabular}

Ankete katılan çalışanların "Çalıştığım şirkette kalmak benim için bir istekten çok bir gerekliliktir." değişkenine verdiği cevapları incelediğimizde, 
çalışanların \%25'i katılmıorum, \%22'si hiç katılmıorum, \%20'si fikrim yok, \%19,50'si tamamen katıliyorum ve \%13,50'si katıliyorum cevabi vermiştir. Bu sonuç çalışanların devamlılık bağlılık düzeylerinin yüksek olduğunu göstermektedir.

Tablo 18. Çalışanların İstekli Olsalar Bile İşten Ayrılmanın Zor Olması Hakkındaki Düşünceleri

\begin{tabular}{llccc}
\hline & Gruplar & Frekans (n) & Yüzde\% & Kümülâtif \% \\
\hline Şu anda, istesem bile & Hiç Katılmıorum & 32 & $24,5 \%$ & 25 \\
bu şirketten ayrılmam & Katılmiyorum & 26 & $20 \%$ & 45 \\
benim için çok zordur. & Fikrim Yok & 7 & $5 \%$ & 50 \\
& Katılıyorum & 35 & $27 \%$ & 77 \\
& Tamamen Katılıyorum & 30 & $23,5 \%$ & 100 \\
& Toplam & 130 & $100 \%$ & \\
\hline
\end{tabular}

Ankete katılan çalışanların "Şu anda, istesem bile bu şirketten ayrılmam benim için çok zordur." değişkenine verdiği cevapları incelediğimizde, çallşanların \%27'si katılıyorum, \%24,5'i hiç katılmıorum, \%23,5'i tamamen katılıyorum, \%20'si katılmıyorum ve \%5'i fikrim yok cevabı vermiştir. Bu sonuç çalışanların devamlılık bağlılık düzeylerinin yüksek olduğunu göstermektedir.

Tablo 19. Şirketten Ayrılma Hakkındaki Düşünceler

\begin{tabular}{lllll}
\hline & Gruplar & $\begin{array}{l}\text { Frekans } \\
\text { (n) }\end{array}$ & Yüzde\% & Kümülâtif \% \\
\hline Menfaatim olsa bile Şirke- & Hiç Katılmıyorum & 14 & $10 \%$ & 10 \\
timden ayrılmanın doğru & Katılmıorum & 23 & $18 \%$ & 28 \\
olmadığını düşünüyorum. & Fikrim Yok & 28 & $21 \%$ & 49 \\
& Katılıyorum & 36 & $28,5 \%$ & 78 \\
& Tamamen Katılıyorum & 29 & $22,5 \%$ & 100 \\
& Toplam & 130 & $100 \%$ & \\
\hline
\end{tabular}

Ankete katılan çalışanların "Menfaatim olsa bile Şirketimden ayrılmanın doğru olmadığını düşünüyorum."değişkenine verdiği cevapları incelediğimizde, çalışanların \%18'i katılmıyorum, \%10'u hiç katılmıyorum, \%21'i fikrim yok, \%22,50'si tamamen katiliyorum ve \%28,50'i katıllyorum cevab1 vermiştir. Bu sonuç çalışanların çoğunluğunun şirketten ayrılmanın doğru olmadığ1 düşüncesine katıldığını ve normatif bağlılık düzeylerinin yüksek olduğunu göstermektedir. 
Tablo 20. Çalışanların Sadakat Hakkındaki Düşünceleri

\begin{tabular}{lllll}
\hline & Gruplar & $\begin{array}{l}\text { Frekans } \\
\text { (n) }\end{array}$ & Yüzde\% & Kümülâtif \% \\
\hline Bu şirkette & Hiç Katılmiyorum & 22 & $17 \%$ & 17 \\
çalışmaya devam etme & Katılmiyorum & 28 & $21 \%$ & 38 \\
nedenlerimden biri de & Fikrim Yok & 20 & $16 \%$ & 54 \\
sadakatin önemli olduğuna & Katıliyorum & 33 & $25 \%$ & 79 \\
inanmamdır. & Tamamen Katılıyorum & 27 & $21 \%$ & 100 \\
& Toplam & 130 & $100 \%$ & \\
\hline
\end{tabular}

Ankete katılan çalışanların "Bu şirkette çalışmaya devam etme nedenlerimden biri de sadakatin önemli olduğuna inanmamdır." değişkenine verdiği cevapları incelediğimizde, çalışanların \%25'i katılıyorum, \%21'i tamamen katılıyorum, \%21'i katılmıyorum, \%17'si hiç katılmıyorum ve \%16's1 fikrim yok cevabı vermiştir. Bu sonuç çalışanların şirket sadakati ile normatif bağlllık düzeylerinin yüksek olduğunu göstermektedir.

Tablo 21. Şirkete Olan Duygusal Bağlılık Hakkındaki Düşünceler

\begin{tabular}{lllll}
\hline & Gruplar & $\begin{array}{l}\text { Frekans } \\
\text { (n) }\end{array}$ & Yüzde\% & Kümülâtif \% \\
\hline Bu şirkete kendimi “duy- & Hiç Katılmıyorum & 36 & $28 \%$ & 28 \\
gusal olarak bağlı" & Katılmiyorum & 49 & $38 \%$ & 66 \\
hissetmiyorum. & Fikrim Yok & 23 & $18 \%$ & 84 \\
& Katıllyorum & 14 & $10 \%$ & 94 \\
& Tamamen Katıllyorum & 8 & $6 \%$ & 100 \\
& Toplam & 130 & $100 \%$ & \\
\hline
\end{tabular}

Ankete katılan çalışanların "Bu şirkete kendimi "duygusal olarak bağlı" hissetmiyorum." değişkenine verdiği cevapları incelediğimizde, çalışanların \%38'i katılmıyorum, \%28'i hiç katılmıyorum, \%18'i fikrim yok, \%10'u katıl1yorum ve \%6'sı tamamen katıliyorum cevabı vermiştir. Bu sonuç çalışanların şirketlerine duygusal bağlı olduklarını ve duygusal bağllık düzeylerinin yüksek olduğunu göstermektedir.

Tablo 22. Şirket Özel Bir Anlam İfade Ediyor mu?

\begin{tabular}{lllll}
\hline & Gruplar & $\begin{array}{l}\text { Frekans } \\
\text { (n) }\end{array}$ & Yüzde\% & Kümülâtif \% \\
\hline Bu şirketin benim için özel & Hiç Katılmıyorum & 19 & $14 \%$ & 14 \\
bir anlamı vardır. & Katılmıyorum & 26 & $20 \%$ & 34 \\
& Fikrim Yok & 11 & $8 \%$ & 42 \\
& Katılıyorum & 44 & $33 \%$ & 75 \\
& Tamamen Katılıorum & 30 & $25 \%$ & 100 \\
& Toplam & 130 & $100 \%$ & \\
\hline
\end{tabular}


Ankete katılan çalışanların "Bu şirketin benim için özel bir anlamı vardır." değişkenine verdiği cevapları incelediğimizde, çalışanların \%33'ü katılıyorum, \%25'i tamamen katıllyorum, \%20'si katılmıorum, \%14'ü hiç katılmıyorum, \%8'i fikrim yok ve cevabı vermiştir. Bu sonuç çalışanlar için şirketin özel anlam ifade ettiğini ve duygusal bağlllık düzeylerinin yüksek olduğunu göstermektedir.

Ayrıca örgütsel bağlılık ölçeğinin tanımlayıcı istatistikleri incelendiğinde, örneklemi oluşturan katılımcıların en çok katıldıkları maddeler şunlardır;

- Kariyerimin kalan kısmını bu şirkette geçirmekten çok mutlu olurum.

- Çalışanların şirketlerine her zaman bağlı olmaları gerektiğine inanıyorum.

- Menfaatim olsa bile şirketimden ayrılmanın doğru olmadığını düşünüyorum.

- Bu şirketin benim için özel bir anlamı vardır.

Örgütsel bağlılık ölçeğinde yer alan maddelere ilişkin değerlendirmede 5 'li likert ölçeği kullanılmıştır. Sorulara en düşük 1 , en yüksek 5 puan verilmiş ve değişim aralığ 4 olarak hesaplanmıştır. Bu durumda derecelendirme için sınıf aralığı 4/5=0,80 olarak elde edilmiştir. Bu durumda ilgili sınıflandırma şu şekildedir;

$$
\begin{aligned}
& 1.00-1.80 \text { =Çok düşük düzeyde örgütsel bağllılk algısı. } \\
& 1.81-2.60=\text { Düşük düzeyde örgütsel bağlılık algısı. } \\
& 2.61-3.40=\text { Orta düzeyde örgütsel bağll1ık algısı. } \\
& 3.41-4.20=\text { Yüksek düzeyde örgütsel bağlılık algısı. } \\
& 4.21-5.00=\text { =Çok yüksek düzeyde örgütsel bağl1lık algısı } \text {. }
\end{aligned}
$$

\section{Tablo 23. Örgütsel Bağhllık Ölçeğine İlişkin Betimsel İstatistikler}

\begin{tabular}{lcc}
\hline & $\overline{\mathbf{X}}$ & Std. Sapma \\
\hline Çalıştı̆̆ım şirkette arkadaşlarımla olan ilişkilerimden memnunum. & 3,918 & 0,722 \\
\hline Kariyerimin kalan kısmını bu şirkette geçirmekten çok mutlu olurum. & 3,654 & 1,316 \\
\hline Çalıştığım şirkette, kendimi “aileden biri” gibi hissediyorum. & 3,526 & 1,093 \\
\hline Çalışanların şirketlerine her zaman bağlı olmaları gerektiğine inanıyorum. & 3,730 & 1,118 \\
\hline Şu anda, bu şirkette kalmak benim için bir istekten çok bir gerekliliktir. & 2,480 & 1,483 \\
\hline Şu anda, istesem bile bu şirketten ayrılmam benim için çok zordur. & 3,319 & 1,435 \\
\hline Menfaatim olsa bile Şirketimden ayrılmanın doğru olmadı̆̆ını düşünüyorum. & 3,653 & 1,314 \\
\hline Bu şirkette çalışmaya devam etme nedenlerimden biri de sadakatin önemli oldu- & 3,317 & 1,433 \\
ğuna inanmamdır. & 2,705 & 1,309 \\
\hline Bu şirkete kendimi “duygusal olarak bağlı” hissetmiyorum. & 3,845 & 1,257 \\
\hline Bu şirketin benim için özel bir anlamı vardır. & 3,414 & 1,103 \\
\hline Genel & & \\
\hline
\end{tabular}


Sonuç olarak; örgütsel bağlllık ölçeğine ilişkin genel ortalama incelendiğinde, skorun yüksek düzeye denk geldiği gözlenmiştir yani çalışanların örgütsel bağlllığa yönelik algılarının yüksek düzeyde olduğu saptanmıştır.

\section{Ana Hipotez ve Alt Hipotezlerin Test Edilmesi}

"Çalışanların iş sağlığı ve güvenliği algı düzeyleri ile örgütsel bağlılık düzeyi arasında anlamlı bir ilişki vardır." ana hipotezini test etmek için korelasyon analizi uygulanmıştır. Korelasyon analizinin uygulanmasında Pearson korelasyon katsayısı kullanılmıştır. "Korelasyon katsayısının +1 ile -1 değerleri arasında değiştiği ve +1 'e yaklaştıkça iki değer arasındaki ilişkinin pozitif yönlü ve çok kuvvetli ilişki olacağı, -1'e yaklaştıkça iki değer arasındaki ilişkinin negatif yönlü ve çok kuvvetli olacağı bilinmektedir. Değişkenler birlikte artıyor ise veya korelasyon katsayısı pozitif işaret alıyor ise, ilişkinin pozitif yönde olduğunu gösterir. Negatif işaret alması ise, değişkenlerden biri artarken diğeri azalıyor demektir ve ilişkinin negatif yönde olduğu anlaşılır." (Cohen, 1988) analiz sonuçları Tablo 24'de verilmiştir.

Tablo 24. İş Sağlı̆̆ı ve Güvenliği ile Örgütsel Bağhllk Arasındaki Korelasyon Sonuçları

\begin{tabular}{llll}
\hline & $\begin{array}{l}\text { Korelasyon } \\
\text { Katsayısı (r) }\end{array}$ & $\begin{array}{l}\text { Anlamlılık Düzeyi } \\
(p)\end{array}$ & $\mathbf{N}$ \\
\hline Örgütsel Bağlılık (Genel) & 0,413 & 0,000 & 130 \\
\hline
\end{tabular}

Örgütsel bağlıllı̆a bağlı ortalama değer tespit edilerek iş sağllğı ve güvenliği alıgısı ile kolerasyon testine sokulmuştur. Çalışanların iş sağlı̆̆ 1 ve güvenlik algıları ile örgütsel bağlılık arasındaki ilişkiyi belirlemek için elde edilen 0,413 korelasyon katsayısı 0,01 önem düzeyinde istatistiksel olarak anlamlı bulunmuştur. Çalışanların iş sağlığı ve güvenlik algıları ile örgütsel bağlllık arasında pozitif yönde bir ilişki söz konusudur. İş sağlığı ve güvenliği konusundaki çalışan algılarının artması örgütsel bağlılığa olumlu olarak yansımaktadır. Bu durumda $\mathbf{H}_{1}$ Çalışanların iş sağlığı ve güvenliği algı düzeyleri ile örgütsel bağlılık düzeyi arasında anlamlı bir ilişki vardır alternatif hipotez kabul edilmiştir.

Çalışanların iş sağlığı ve güvenlik algıları ile duygusal bağlılık arasındaki ilişkiyi belirlemek için elde edilen 0,357 korelasyon katsayısı 0,01 önem düzeyinde istatistiksel olarak anlamlı bulunmuştur. Çalışanların iş sağlığı ve 
güvenlik algıları ile duygusal bağlılık arasında pozitif yönde bir ilişki söz konusudur. İş sağlığı ve güvenliği konusundaki çalışan algılarının artması duygusal bağlılığa olumlu olarak yansımaktadır. Bu durumda $\mathbf{H}_{1-a}$ Çalışanların iş sağlığı ve güvenliği algı düzeyleri ile duygusal bağllılı düzeyi arasında anlamlı bir ilişki vardır alternatif hipotez kabul edilmiştir.

Çalışanların iş sağlığı ve güvenlik algıları ile normatif bağlılık arasındaki ilişkiyi belirlemek için elde edilen 0,362 korelasyon katsayısı 0,01 önem düzeyinde istatistiksel olarak anlamlı bulunmuştur. Çalışanların iş sağlığı ve güvenlik algıları ile normatif bağlılık arasında pozitif yönde bir ilişki söz konusudur. İş sağlığı ve güvenliği konusundaki çalışan algılarının artması normatif bağlılığa olumlu olarak yansımaktadır. Bu durumda $\mathbf{H}_{1-b}$ Çalışanların iş sağlığ1 ve güvenliği algı düzeyleri ile normatif bağlılık düzeyi arasında anlamlı bir ilişki vardır alternatif hipotez kabul edilmiştir.

Çalışanların iş sağlığı ve güvenlik algıları ile devam bağlılığı arasındaki ilişkiyi belirlemek için elde edilen 0,375 korelasyon katsayısı 0,01 önem düzeyinde istatistiksel olarak anlamlı bulunmuştur. Çalışanların iş sağlı̆̆ 1 ve güvenlik algıları ile devam bağlılığı arasında pozitif yönde bir ilişki söz konusudur. İşs sağlı̆̆1 ve güvenliği konusundaki çalışan algilarının artması devam bağlılığına olumlu olarak yansımaktadır. Bu durumda $\mathbf{H}_{1-c}$ Çalışanların iş sağlığı ve güvenliği algı düzeyleri ile devamlılık bağlllık düzeyi arasında anlamlı bir ilişki vardır alternatif hipotez kabul edilmiştir.

\section{Alt Hipotezin Test Edilmesi}

Çalışanların iş sağlığı ve güvenliği algıları ile örgütsel bağlılık düzeylerini demografik özelliklerine göre incelemek için ilgilenilecek demografik değişkenin durumuna göre bağımsız örneklem $t$ testi veya tek yönlü varyans analizi (ANOVA) kullanılmıştır.

\section{İşSağlığı ve Güvenliği Algılarının ve Örgütsel Bağhlık Düzeylerinin Yaşa} Göre Farklılaşması: Çalışanların iş sağlığı ve güvenliği algılarının ve örgütsel bağlllık düzeylerinin yaşa göre farklılık gösterip göstermediğini belirlemek amacı ile Tek Yönlü Varyans Analizi (ANOVA) uygulanmış ve sonuçları Tablo 26' da verilmiştir. 
Tablo 26. Yaşa Göre Anova Sonuçları

\begin{tabular}{lllllll}
\hline & Yaş Aralı̆̆1 & $\mathbf{N}$ & $\overline{\mathbf{X}}$ & $\mathbf{S s}$ & $\mathbf{f}$ & $\mathbf{p}$ \\
\hline \multirow{3}{*}{ İş sağlı̆̆1 ve güvenliği } & $18-25$ & 10 & 4,291 & 0,261 & & \\
& $26-33$ & 29 & 4,340 & 0,503 & & \\
& $33-40$ & 57 & 4,326 & 0,456 & 0,253 & 0,908 \\
& 41 üzeri & 34 & 4,202 & 0,278 & & \\
\hline \multirow{2}{*}{ Örgütsel bağlılık } & $18-25$ & 10 & 3,556 & 0,333 & & \\
& $26-33$ & 29 & 3,872 & 0,435 & & \multirow{2}{*}{0,004} \\
\hline
\end{tabular}

Çalışanların iş sağlığı ve güvenliği algılarının yaşlarına göre farklılık gösterip göstermediğini belirlemek amacı ile hesaplanan 0,253 f istatistik değeri 0,05 önem düzeyinde istatistiksel olarak anlamlı bulunmamıştır $(\mathrm{p}=0,908>0,05)$. Çalışan yaşlarının iş sağlığı ve güvenliği algilarında farklılığa neden olmadığı saptanmıştır. Ortalamalar incelendiğinde, tüm yaş grubundan çalışanların iş sağlığı ve güvenliği algilarının çok yüksek düzeyde olduğu saptanmıştır. $\mathbf{B u}$ durumda $\mathbf{H}_{2}$ iş sağllğı ve güvenliği algisı yaşa göre farklılık göstermektedir hipotezi red edilmiştir.

Çalışanların örgütsel bağlılık algılarının yaşlarına göre farklılık gösterip göstermediğini belirlemek amacı ile hesaplanan 4,169 f istatistik değeri 0,05 önem düzeyinde istatistiksel olarak anlamlı bulunmuştur. $(p=0,004>0,05)$. Çalışan yaşlarının örgütsel bağlılık algılarında farklılığa neden olduğu saptanmıştır. Ortalamalar incelendiğinde, tüm yaş grubundan çalışanların örgütsel bağlılık algılarının yüksek düzeyde olduğu saptanmıştır. Bu durumda $\mathbf{H}_{3}$ Örgütsel bağlılık düzeyi yaşa göre farklılık göstermektedir hipotezi kabul edilmiştir.

\section{İşS Sağlı̆̆ı ve Güvenliği Algılarının ve Örgütsel Bağhlık Düzeylerinin Ĕ̆itim}

Durumuna Göre Farklılaşması: Çalışanların iş sağlı̆̆ ve güvenliği algılarının ve örgütsel bağll1ık düzeylerinin eğitim yaşa göre farklılık gösterip göstermediğini belirlemek amacı ile Tek Yönlü Varyans Analizi (ANOVA) uygulanmış ve sonuçları Tablo-27'de verilmiştir. 
Tablo 27. Eğitim Durumuna Göre Anova Sonuçları

\begin{tabular}{|c|c|c|c|c|c|c|}
\hline & Eğitim Durumu & $\mathbf{N}$ & $\overline{\mathbf{X}}$ & Ss & $\mathbf{f}$ & $\mathrm{p}$ \\
\hline \multirow{4}{*}{$\begin{array}{l}\text { İş sağlığ́1 } \\
\text { ve güvenliği }\end{array}$} & İlköğretim & 23 & 4,274 & 0,364 & \multirow{4}{*}{4,544} & \multirow{4}{*}{0,004} \\
\hline & Ortaöğretim & 54 & 4,270 & 0,451 & & \\
\hline & Meslek Yüksekokulu & 35 & 4,559 & 0,338 & & \\
\hline & Üniversite & 18 & 4,556 & 0,430 & & \\
\hline \multirow{4}{*}{$\begin{array}{l}\text { Örgütsel } \\
\text { bağlılık }\end{array}$} & İlköğretim & 23 & 3,627 & 0,345 & & \\
\hline & Ortaöğretim & 54 & 3,759 & 0,398 & \multirow{3}{*}{5,015} & \multirow{3}{*}{0,003} \\
\hline & Meslek Yüksekokulu & 35 & 3.835 & 0,470 & & \\
\hline & Üniversite & 18 & 4,225 & 0,308 & & \\
\hline
\end{tabular}

Çalışanların iş sağlı̆̆ı ve güvenliği algılarının eğitim durumlarına göre farklılık gösterip göstermediğini belirlemek amacı ile hesaplanan 4,544 f istatistik değeri 0,01 önem düzeyinde istatistiksel olarak anlamlı bulunmuştur $(p=0,004<0,01)$. Çalışan eğitim durumlarının iş sağlığı ve güvenliği alg1larında farklılığa neden olduğu saptanmıştır. Bu durumda $\mathbf{H}_{4}$ iş sağlığı ve güvenliği algısı eğitim durumuna göre farklılık göstermektedir hipotezi kabul edilmiştir.

Çalışanların örgütsel bağlllık düzeylerinin eğitim durumlarına göre farklılık gösterip göstermediğini belirlemek amacı ile hesaplanan 5,015 f istatistik değeri 0,01 önem düzeyinde istatistiksel olarak anlamlı bulunmuştur $(p=0,003<0,01)$. Çalışan eğitim durumlarının örgütsel bağlllık düzeylerinde farklılığa neden olduğu saptanmıştır. Bu durumda $\mathbf{H}_{5}$ Örgütsel bağl1lık düzeyi eğitim durumuna göre farklılık göstermektedir hipotezi kabul edilmiştir.

$\dot{I}_{s ̧}$ Sağhlğı ve Güvenliği Algılarnın ve Örgütsel Bağhllk Düzeylerinin Çalışma Süresi Durumuna Göre Farkhlaş̧ması: Çalışanların iş sağlığı ve güvenliği algılarının ve örgütsel bağlllık düzeylerinin işletmedeki çalışma süresine göre farklılık gösterip göstermediğini belirlemek amacı ile Tek Yönlü Varyans Analizi (ANOVA) uygulanmış ve sonuçları Tablo 33'de verilmiştir.

Çalışanların iş sağlığı ve güvenliği algılarının işletmedeki çalışma sürelerine göre farklılık gösterip göstermediğini belirlemek amacı ile hesaplanan 1,383 $\mathrm{f}$ istatistik değeri 0,05 önem düzeyinde istatistiksel olarak anlamlı bulunmamıştır ( $\mathrm{p}=0,284>0,05)$. Çalışanların işletmedeki çalışma sürelerinin iş sağlı̆̆ ve güvenliği algılarında farklılığa neden olmadığı saptanmıştır. Bu durumda $\mathbf{H}_{6}$ iş sağlığ1 ve güvenliği alg1sı çalışma süresi durumuna göre farklılık göstermektedir hipotezi red edilmiştir. 
Tablo 33. Çalışma Süresi Durumuna Göre Anova Sonuçları

\begin{tabular}{|c|c|c|c|c|c|c|}
\hline & Çalışma Süresi & $\mathbf{N}$ & $\overline{\mathbf{X}}$ & Ss & $\mathrm{f}$ & $\mathrm{p}$ \\
\hline \multirow{4}{*}{$\begin{array}{l}\text { İşs sağllğı } \\
\text { ve güvenliği }\end{array}$} & $0-3 Y_{11}$ & 23 & 4,386 & 0,533 & \multirow{4}{*}{1,383} & \multirow{4}{*}{0,284} \\
\hline & 3-6 Y 11 & 29 & 4,368 & 0,508 & & \\
\hline & 6-9 Yil & 41 & 4,347 & 0,396 & & \\
\hline & 9-12 Y 11 & 37 & 4,241 & 0,338 & & \\
\hline \multirow{4}{*}{$\begin{array}{l}\text { Örgütsel } \\
\text { bağllllık }\end{array}$} & 0-3 Yil & 23 & 3,869 & 0,509 & \multirow{4}{*}{3,288} & \multirow{4}{*}{0,023} \\
\hline & 3-6 Y 11 & 29 & 3,841 & 0,471 & & \\
\hline & 6-9 Yil & 41 & 3.719 & 0,384 & & \\
\hline & 9-12 Yll & 37 & 3,654 & 0,305 & & \\
\hline
\end{tabular}

Çalışanların örgütsel bağlılık düzeylerinin işletmedeki çalışma sürelerine göre farklılık gösterip göstermediğini belirlemek amacı ile hesaplanan 3,288 $\mathrm{f}$ istatistik değeri 0,05 önem düzeyinde istatistiksel olarak anlamlı bulunmuştur $(p=0,023<0,05)$. Çalışanların işletmedeki çalışma sürelerinin örgütsel bağlllık düzeylerinde farklılığa neden olduğu saptanmıştır. Bu durumda $\mathbf{H}_{7}$ Örgütsel bağlılık düzeyi çalışma süresi durumuna göre farklılık göstermektedir hipotezi kabul edilmiştir.

\section{Sonuç}

Sanayi devriminin ardından iş kazaları ve meslek hastalıkları sonucunda hayatını kaybeden çalışanların sayısının artması ile birlikte iş sağlığı ve güvenliği uygulamaları daha da önemli hale gelmeye başlamıştır. Teknolojik gelişmelere bağlı olarak çalışma koşulları değişmiş, çalışanlar için iş kazaları ve meslek hastalıkları büyük bir risk haline gelmiştir. İş sağlığı ve güvenliği uygulamaları çalışanların sağlık ve güvenliklerini korumanın yanında çalışma ortamında meydana gelebilecek olan risklere karşı önlem almayı amaçlamaktadır. Bu önlem çalışanların zarar görmesini engellemenin yanında, sosyal ve ekonomik kayıpları da azaltmaktadır.

Günümüz örgütleri için en önemli sermaye beşeri sermayedir. Beşeri sermaye, çalışanların bilgi, beceri ve yeteneklerini kapsamakla birlikte örgütün sahip olduğu toplanmış insan yeteneğidir. Büyük bir hızla ilerleyen teknoloji ve artan rekabet ortamı, örgütlerde insan kaynağının en etkin şekilde kullanılmasını gerektirmektedir. Örgütlerin hedefledikleri başarıya ulaşmalarında ve varlıklarını sürdürebilmelerinde çalışanlar önemli bir yere sahiptir. Yaptıkları işi severek ve memnuniyet duyarak yapan, örgütün 
değerlerini kendi amaç ve değerleri gibi benimseyen çalışanlar örgütün başarısına katkıda bulunmaktadırlar.

$\mathrm{Bu}$ çalışmanın temel amacı, iş sağlı̆̆ı ve güvenliği uygulamalarının örgütsel bağlllığa olan etkisini incelemektir. Bu amaç doğrultusunda işletme çalışanlarının iş sağlı̆̆ı ve güvenliğini algılama düzeyleri ile örgütsel bağlllık düzeyleri araştırılmıştır.

Çalışmanın ilk bölümünde iş sağlığı ve güvenliği konusu, ikinci bölümde ise örgütsel bağlılık konusu çeşitli yönleriyle açıklanmıştır. Çalışmanın üçüncü ve son bölümünde İstanbul'da bulunan özel bir çevre yönetimi şirketinde Saha Hizmetleri Müdürlüğüne bağlı 130 çalışan üzerinde uygulama araştırması yapılmıştır.

Araştırma için 3 bölümden oluşan bir anket hazırlanmış ve araştırmanın uygulama aşamasında çalışanlardan elde edilen cevaplar iki bölümde incelenmiştir. Bunlar; iş sağlı̆̆ı ve güvenliği uygulamalarını algılama düzeyleri ve örgütsel bağlllık düzeyleridir. Ankete katılan çalışanlar tarafından verilen cevapların analizleri yapılarak aşağıda belirtilen sonuçlara ulaşılmıştır.

Sayıca erkek çalışanlar kadın çalışanlardan fazladır. Çalışanlar 33-40 yaş aralığında, çoğunluğu ortaöğretim mezunu ve beden işçisidir. Evli olan çalışanların oranı oldukça yüksek ve büyük bir bölümü 6 ila 9 yıl arasında aynı şirkette çalışmaktadır. Aylık gelir durumuna göre $1.401 \mathrm{TL}-2.500 \mathrm{TL}$ arasında aylık gelir elde etmektedirler.

İş sağlığı ve güvenliği ölçeğine ilişkin genel ortalama incelendiğinde, skorun çok yüksek düzeye denk geldiği gözlenmiş yani çalışanların iş sağl1ğ1 ve güvenliğine yönelik algılarının çok yüksek düzeyde olduğu saptanmiştır.

Örgütsel bağlllık ölçeğine ilişkin genel ortalama incelendiğinde, skorun yüksek düzeye denk geldiği gözlenmiş yani çalışanların örgütsel bağlılığa yönelik algılarının yüksek düzeyde olduğu saptanmıştır.

Çalışanların iş sağlığı ve güvenlik algıları ile örgütsel bağlılık arasında pozitif yönde bir ilişki söz konusudur. İş sağlığ1 ve güvenliği konusundaki çalışan algılarının artması örgütsel bağlılığa olumlu olarak yansımaktadır. Çalışanların iş sağlığı ve güvenliği alg1 düzeyleri ile örgütsel bağlılık düzeyi arasında anlamlı bir ilişki vardır.

Çalışanların iş sağlığı ve güvenlik algıları ile duygusal bağlılık arasında pozitif yönde bir ilişki söz konusudur. İş sağlığı ve güvenliği konusundaki çalışan algılarının artması duygusal bağlılığa olumlu olarak yansımaktadır. 
Çalışanların iş sağlığı ve güvenliği algı düzeyleri ile duygusal bağlılık düzeyi arasında anlamlı bir ilişki mevcuttur.

Çalışanların iş sağlığı ve güvenlik algıları ile normatif bağlılık arasında pozitif yönde bir ilişki söz konusudur. İş sağllğı ve güvenliği konusundaki çalışan algılarının artması normatif bağlılığa olumlu olarak yansımaktadır. Çalışanların iş sağlığı ve güvenliği algı düzeyleri ile normatif bağlılık düzeyi arasında anlamlı bir ilişki vardır.

Çalışanların iş sağlığı ve güvenlik algıları ile devam bağlılığı arasında pozitif yönde bir ilişki söz konusudur. İş sağlığı ve güvenliği konusundaki çalışan algılarının artması devam bağlılığına olumlu olarak yansımaktadır. Çalışanların iş sağlığı ve güvenliği algı düzeyleri ile devamlılık bağlılık düzeyi arasında anlamlı bir ilişki vardır.

Çalışanların cinsiyetlerinin iş sağlığı ve güvenliği algılarında bir farklılığa neden olmadığı saptanmıştır. İş sağlığı ve güvenliği algısı cinsiyete göre farklılık göstermemektedir.

Çalışanların cinsiyetlerinin genel örgütsel bağlılık algılarında bir farklılığa neden olmadığı saptanmıştır. Genel örgütsel bağlılık düzeyi cinsiyete göre farklılık göstermemektedir.

Çalışan yaşlarının iş sağlığı ve güvenliği algılarında farklılığa neden olmadığı saptanmıştır. İş sağlığı ve güvenliği algısı yaşa göre farklılık göstermemektedir.

Çalışan yaşlarının örgütsel bağlllık algılarında farklılığa neden olduğu saptanmıştır. Örgütsel bağlılık düzeyi yaşa göre farklılık göstermektedir.

Çalışan eğitim durumlarının iş sağlığı ve güvenliği algılarında farklılığa neden olduğu saptanmıştır. İş sağlığı ve güvenliği algısı eğitim durumuna göre farklılık göstermektedir.

Çalışan eğitim durumlarının örgütsel bağlılık düzeylerinde farklılığa neden olduğu saptanmıştır. Örgütsel bağlllık düzeyi eğitim durumuna göre farklılık göstermektedir.

Çalışanların işletmedeki çalışma sürelerinin iş sağlığı ve güvenliği algılarında farklılığa neden olmadığı saptanmıştır. İş sağllğı ve güvenliği algısı çalışma süresi durumuna göre farklılık göstermemektedir.

Çalışanların işletmedeki çalışma sürelerinin örgütsel bağlılık düzeylerinde farklılığa neden olduğu saptanmıştır. Örgütsel bağlılık düzeyi çalışma süresi durumuna göre farklılık göstermektedir. 


\section{EXTENDED ABSTRACT}

\section{The Impact of Occupational Health and Safety Practices on Organizational Commitment: A Field Study \\ Mehmet Güler \\ İstanbul University}

Occupational health and safety practices, which have a great importance in the work environment, are one of the issues that need to ensure the participation of employees in management and thus their organizational commitment. Occupational health and safety is one of the most important legal aspects of working life. Occupational health and safety is the elimination or reduction of the health problems and occupational risks that workers are exposed to due to the physical environmental conditions at the workplace during the work. As a result of work accidents, employees are injured, lose their lives and experience serious economic losses.

Occupational health and safety in today's businesses is considered as an issue that needs to be emphasized because it affects employee loyalty, attendance, motivation, efficiency, job satisfaction and productivity. In this context, this study examines the relationship between $\mathrm{OSH}$ practices and job satisfaction and organizational commitment.

In the National and International literature, it is observed that a large number of literature reviews and field studies have been conducted on occupational health and safety. However, the number of studies examining the relationship between occupational health and safety and job satisfaction and organizational commitment is very low. In the first part of the study, brief information about occupational health and safety, job satisfaction and organizational commitment is given. Then, the general studies of the studies conducted that examine the relationship between these three concepts are summarized. In the last part, the findings are evaluated and suggestions about the subject are presented.

OHS is one of the most important rights and social needs of employees. Practices and audits in the field of OHS are of great importance so that employees do not see their right to life at work in danger. Employees are pleased 
to work in the organization, as practices in the field of OHS contribute positively to employees' perception of OHS. This situation positively affects the job satisfaction and organizational commitment of the employee. It is also expected that the performance of employees who are connected to the organization in this way and who are satisfied with their job will increase.

According to demographic characteristics, OHS, job satisfaction and organizational commitment have been observed to differ. In the comparison made by gender, it was determined that the level of job satisfaction of women is higher than that of men. In the comparison made by provinces, it was determined that the level of job satisfaction was higher in Istanbul. Finally, when we look at age, it is determined that as age increases, organizational commitment and OHS perception increase. In today's business world, where intense competition is experienced, the contribution and importance of human resources cannot be ignored in achieving competitive advantage. In this respect, considering the losses and losses that may arise from the OHS-related deficiencies and the determining role of the mentioned human resource, it is seen as the most rational way for the companies to implement their OHS practices at the highest level.

\section{Kaynakça / References}

Amponsah-Tawiah, K. ve Mensah, J. (2016). Occuppional health and safety and organizational commitment: Evidence from the Ghanaian mining industry. Safety and Health at Job, 1-6.

Aybora, D. (2015). İş̧̧i sağhlğı ve güvenliği.Eskişehir:Anadolu Üniversitesi Yayınları. Bilir, N.(2016). İş sağlığı ve güvenliğ̈i profili Türkiye. Ankara: Çalışma ve Sosyal Güvenlik Bakanlığı. 2016.

Ceylan, H. (2011). Türkiye'deki iş kazalarınn genel görünümü ve gelişmiş ülkelerle kıyaslanması. International Journal of Engineering Research and Development, 3(2), 18-24.

Cohen, J. (1988). Statistical power analysis for the behavioral sciences (2nd ed.) Hillsdale, NJ: Lawrence ErlbaumAssociates.

Çınar, O. ve Gündoğdu Ç. (2019) İş Sağllğı-Güvenliğ̈i, İş Tatmini ve Örgütsel Bağlllık Arasındaki İlişkinin İncelenmesi: Erzurum ve İstanbul Uygulaması. İş ve Hayat Dergisi, 9, 231-247.

Doğan, E. Ş.(2013). Örgüt kültürü ve örgütsel bağlllık. İstanbul: Türkmen Kitapevi. 
Ekici, G. (2008). Sınıf yönetimi dersinin öğretmen adaylarının öğretmen özyeterlik alg1 düzeyine etkisi. Hacettepe Üniversitesi Ĕ̆itim Fakültesi Dergisi, 35(35), 98-110.

Gül, H. (2016). Örgütsel bağlılık yaklaşımlarının mukayesesi ve değerlendirmesi. Gaziosmanpaşa Üniversitesi Zile Meslek Yüksek Okulu Dergisi, 1(4),37-56.

Gyekye, S.A.(2015).Workers' perceptions of workplace safety and job satisfaction.International Journal of Occupational Safety and Ergonomics,11(3),291302.

İnce, M. ve Gül, H.(2005). Yönetimde yeni bir paradigma: Örgütsel bağlılık. Konya. Çizgi Kitapevi.

Kargar, M. (2012). Evaluation of organizational commitment of employees in university; case study: Islamic Azad University. Journal of Basic and Applied Scientific Research, 2(5), 5017-5021.

Khan, M. S.. vd. (2011). Influence of employee compensation on organizational commitment and job satisfaction: A case study of educational sector of Pakistan. International Journal of Business and Social Science, 2(8), 114-131.

Kılıç, G. ve Selvi, M.S. (2009). The effects of occupational health and safety risk factors on satisfaction in hotel enterprises. Ege Akademik Bakış Dergisi, 9(3), 903-921.

Omusulah, I.D. (2013). Perceived influence of occupational health and safety practices on job satisfaction among employees in chemelil sugar company limited. Master Thesis. The University of Nairobi (Kenia).

Özdemir, E.(2015). İçsel iş çevresi, kişilik özellikleri ve sektör agisinin iş tatmini ve iş performansi üzerindeki etkisi: Alanya Konaklama İşletmeleri örneği. Akdeniz Üniversitesi, Sosyal Bilimler Enstitüsü, Antalya,

Saldamlı. A.(2009). İşletmelerde örgütsel bağlılık ve işgören performansı. Ankara: Detay Yayıncilik.

Seymen Aytemiz, O. (2008). Örgütsel bağhllı̆̆ı etkileyen örgüt kültürü tipleri üzerine bir araştırma. Ankara:Detay Yayıncılık.

Vural Akıncı, B. ve Gül, C. (2007). Örgüt kültürü. İstanbul: Nobel Yayınevi.

\section{Kaynakça Bilgisi / Citation Information}

Güler, M. (2020). İş sağlığı ve güvenliği uygulamalarının örgütsel bağlılığa olan etkisi: Bir alan araştırması. OPUS-Uluslararası Toplum Araştırmalarn Dergisi, 15(23), 2132-2163. DOI: 10.26466/opus. 627786 